\title{
$\longrightarrow$ \\ Labor and Religious Tolerance in Two Senegalese Daaras
}

\author{
Laura L. Cochrane
}

\begin{abstract}
How do people create their religious selves and a religious culture through their everyday practices and discourses? This article examines residents of two rural daaras (Sufi religious communities) in Senegal and their focus on labor and tolerance as religious practice. It uses concepts of tradition, performativity, and citation to trace the themes of labor and tolerance through historical, political, and present-day applications in Senegal. How do common ways of talking about and practicing labor and tolerance unite a religiously diverse population, both in the daaras and more broadly in Senegal? The daaras' shaykh and residents cite Murid teachings to inform their practices and discussions of labor and tolerance, and have developed the daaras to consciously embed those values in everyday life. These shared practices and discourses form a cultural milieu in which people intentionally participate in the interests of a unified community that can work toward both spiritual and environmental purposes.
\end{abstract}

KEYWORDS: Baay Fall, daara, labor, Muridiyya, practices, Senegal, Sufism, tolerance

Two Senegalese Sufi communities, Ndem and Mbakke Kajoor, are home to daaras, Qur'anic schools in rural or urban areas; daaras also refer to rural communities dedicated to religious study. The two daaras have attracted attention for their work that combines spiritual education alongside addressing environmental crises in this arid region of central Senegal. Thousands of people, some permanent residents and some short-term visitors, participate in their work. The two daaras create a sense of community through practicing and talking about two shared values: labor and religious tolerance. While they cite their own Sufi order's teachings in these practices and discourses, the values of labor and tolerance are shared across the country's religiously diverse population. Senegal's majority-Muslim population mostly adheres to Sufism, an esoteric and intellectual tradition in Islam; other Sunni and Shi'a groups are also prominent in numbers and public voices. Non-Muslim practitioners of indigenous beliefs and Christians are minorities. Sufi and indigenous practices sometimes overlap, such as in rituals of healing, protection, and appeals to ancestors and jinn. Similarly, practices of labor and tolerance are commonalities, yet defined differently across religious affiliations. These publicly visible shared practices add to constant dialogue about respecting religious difference while acknowledging what people share.

The two daaras in Ndem and Mbakke Kajoor are affiliated with the Baay Fall suborder of the Murid Sufi order. The Muridiyya, founded by Shaykh Amadu Bamba in the late nineteenth century, has historical origins in daaras, described below. A Baay Fall shaykh, Sëriñ (a Wolof 
honorific) Babacar Mbow, both started and leads the two daaras, which intentionally emulate Bamba's tradition of a daara, yet in a way that focuses on the region's contemporary needs. Residents and visitors participate in the daaras' projects, including farming, organic gardening, artisanal trades, and education. Their work is spiritually devotional and addresses the region's environmental and economic hardships, echoing Bamba's nineteenth-century teachings. By joining the community-whether for a short visit or a lifetime, and whether Muslim or notresidents and visitors agree to dedicate themselves to laboring in those mutual projects and practicing tolerance within the daara. The daaras' very definition of community relies on these two principles as shared commitments that are consciously lived out.

Daara residents often talk about what they do-be it gardening, working in the health clinic, mediating a conflict, or repairing a fence-as working for God. Fallou Tall, of the Ndem daara, explained, "Bamba said, 'When you work for me, you work for the population'. You are born again when you work. Everything you do, you do for God" (interview, 3 June 2015). Tall's comment exemplified deep knowledge of Bamba's teachings through lifelong study, and also his own internalization of these teachings. Whether working to maintain his home, or carrying out his obligations as manager of the residential area of the Ndem daara, Tall saw work as an act of devotion. Citing Bamba's words and considering one's everyday work as intentional religious practice are meaningful connections to Bamba's teachings: the Murid tradition in contemporary practice.

Gardening or repairing one's house might not look like a religious act, but in this community it is when understood from Bamba's teachings. In other communities, practicing labor and tolerance might involve other actions, such as inviting a destitute neighbor to regular meals or mentoring children. Unity comes from participation in the practices that each community defines as meaningful. Individually and communally practicing values, whether as religious devotion or dedication to the work itself, creates an intentionally unified community.

\section{Citing Traditions}

In this article, I focus on labor and tolerance based on ethnographic data collected during multiple visits to each daara (2009-2018 for Ndem, 2015-2018 for Mbakke Kajoor). My informal conversations, interviews, and observations with women and men took place in homes, community spaces such as courtyards and communal meal areas, and workplaces such as communal kitchens, artisanal workshops, and gardens. In addition to interviews with Sëriñ Babacar Mbow, the shaykh who started the daaras, I reference several of his published books. Periodic return visits enabled further dialogue about previous conversations. I kept up with the two daaras while not in Senegal via social media: contacts in the two daaras sent me videos and images of activities there. All conversations and textual analysis of them were in Wolof and French (unless otherwise indicated, translations are my own). My analysis of this data in all their forms-observations, informal conversations, interviews, and Mbow's published writings-was thematic, looking for ideas (here, the often-repeated themes of labor and tolerance) that people repeat, emphasize, and practice (Cochrane 2021: 23; Goodman 2002: 86-88; Thompson 2019: 123-124).

As the resident of Ndem's daara described above, both discourse and practice are relevant in creating one's self as a religious subject. In Islam, moral outward practices, governed by sharia (derived from the Quran and Sunna and interpreted for cultural context by jurists) create the ethical self. Ethical living was a particular focus of Bamba's teachings, highlighted below. Inward cultivation of the self is bätin, the mystical realm of the soul (Heck 2006: 255-256; Ware 2014: 79). In the daaras, practicing religious teachings about labor and tolerance under a shaykh's directive develops one's outward ethical self, is part of one's internal Sufi path, and creates the daaras' culture. 
Scholars of Islam emphasize practices as creating one's self as a pious person (Abenante and Cantini 2014: 3-4; Abu-Lughod 2006: 1627; Asad 2015: 166-167; Masquelier 2015: 184-190; Mittermaier 2019: 3-8; Ware 2014: 7-9). Scholars of Senegalese and Gambian settings describe how Muslims create their pious selves by practicing the religious teachings they follow, while also adapting to Senegal's often challenging economic realities and secular cultural trends (Augis 2014: 199-201; Buggenhagen 2011: 718; Fioratta 2020: 132-133; Hill 2018: 51-54; Janson 2016: 33-34; Leichtman 2015: 13-18). In Senegal's context of openly public religious practice and dialogue, people define proper ways of living in both cultural and religious ways.

In a rural daara, adherents to a shaykh choose to live in a communal setting under that shaykh's spiritual guidance. Daara residents who are not the shaykh's disciples, no matter their religious affiliation, agree to live within the shaykh's guidelines of comportment and to participate in the work of the daara. Direct ways to cultivate one's religious self with the guidance of the shaykh include Qur'anic education; communal projects; labor in service of God, their shaykh, and their community; practicing community-wide tolerance; and talking about these shared activities after communal meals. These are traditions in the way that Asad (2015: 166-180) describes them: language and behaviors that people consciously use to create their selves. These traditions, Asad writes, are historical, theological, collective, sometimes contested, and applied in specific contexts. Covington-Ward (2016: 4-6) integrates the ideas of tradition and performativity by describing religious practices as having personal and intentional meaning, with both deep cultural histories and contemporary public recognition. These qualities of performance and tradition that Asad and Covington-Ward describe apply to the comportment and discourse residents use in the daaras. People draw on religious and cultural traditions, yet employ them in contemporary ways to address community needs.

I also draw on linguistic anthropology's concept of citation, a way to describe traditions in both a performative and referential manner. People refer to their knowledge of religious tradition discursively in the everyday practice of creating their selves (Cochrane 2016: 4-5; Goodman 2002: 86-88; Goodman et al. 2014: 454-456; Nakassis 2012: 625-626). Referring to Bamba's teachings is an everyday part of conversation in both daaras, as Murid disciples study his writings as well as the Qur'an. In describing how she dealt with a particular problem, Ndem resident Farma Thiam said, "You must have an open heart, it's a recommendation from Sëriñ Touba [an honorific for Bamba]" (interview, 17 February 2016). Ndem resident Moussa Diène explained, "The true models of Islam are Sëriñ Touba and Shaykh Ibra Fall. Shaykh Ibra gave us our way of life and our path" (interview, 29 January 2016). In both of these examples, people described themselves and their approach to life via their connection to Bamba's teachings. Combining the concepts of citation and tradition, citing tradition is both emulative and creative; in both senses, it is performative, as it is an intentional creation of one's self.

Below I describe the historical religious teachings and exemplars of labor and tolerance that people in the daaras apply to their contemporary contexts. Citing these traditions is not only discursive. Practices that cite tradition include comportment that embodies submission to a spiritual guide and participation in communal work that reflects knowledge of religious teachings. While arguing that daara residents create a shared community with these practices and cite them as traditions, I also argue that people implement them in different ways and for different reasons.

\section{The Murid Tradition}

Senegal's majority-Muslim population is majority-Suf, although a number of other Sunni and Shi'a groups are substantial and growing minorities (Augis 2014; Fioratta 2020: 128-136; Leichtman 
2015). Sufi orders are diverse as well, with the Tijaani and Murid orders the most populous in Senegal. These two orders grew in prominence in the late nineteenth century, with leaders who emphasized religious education. This was a chaotic time in Senegambia, as monarchies that had controlled the area for centuries fell to French occupation forces. Sufi leaders, their disciples, and their learning communities offered, as Robinson (1991:150) notes, "a cultural identity distinct from that of the colonizer." Using Murid 'Ajami sources (Wolof written in Arabic script), Ngom (2016: 72) describes the religious pull as well: people were attracted to Bamba's daaras because of Bamba's extraordinary personal merits and "for the ethics-centered doctrine of Islam he advocated."

Sufi orders had been popular in West African scholarly circles since the sixteenth century, particularly the Qadiriyya, a Sufi order founded in the twelfth century in Baghdad. In the eighteenth century, Qadiri Shaykh Sidi al-Mukhtar al-Kunti (1729-1811) expanded Islamic education past the clerical and class-based elite. He taught that once chosen, a shaykh has authority over disciples' spiritual guidance. Al-Kunti's teachings about the centrality of the relationship between shaykh and disciple were influential across West Africa (Batran 1973: 347-348; Ware 2014: 178-179). By relying on this relationship, rather than social status, more people could access religious education. The Qadiriyya became one of the most popular Sufi orders throughout West Africa, including in the Senegambian region. Qadiri cleric and judge Momar Anta Sali Mbakke (d. 1883) established a Qur'anic school in Mbakke Kajoor in 1880, where he attracted many students. His son, Shaykh Amadu Bamba Mbakke (1853-1927), taught at his father's school in Mbakke Kajoor (Babou 2009: 225-227).

Raised and educated in the Qadiriyya, Bamba developed the idea of a shaykh-disciple relationship to expand the reach of religious education even further. He created learning communities focused on education with no restrictions on literacy, social status, or clerical lineage. In the tradition of al-Kunti's teachings, disciples look to the shaykh for knowledge, but also for models of ethical living. As al-Kunti wrote and Bamba taught, service to one's shaykh is an act of voluntary spiritual submission to one's chosen guide (Babou 2003: 312; Batran 1973: 347; Ngom 2016: 70). This practice-oriented pedagogy could be tailored for the educated elite or for illiterate disciples, all living in the same daara (Ndiaye 2015: 118-119; Ngom 2009: 106-107; 2015: 342, 350; Ware 2014: 184).

Historically, shaykhs throughout West Africa sustained themselves through support from their community. Addiya is part of a disciple's voluntary submission, a material offering to a shaykh. Addiya supports the work of shaykhs, who also redistribute it to those in need. It is not a mere economic relationship, however: disciples receive blessings (baraka) for being part of that work and generosity (Bondaz and Bonhomme 2014: 486-489; Buggenhagen 2011: 715-716; 2012: 84-85; Ngom 2016: 87-88; Ware 2014: 184-189). The French colonial economy, which focused on the groundnut cash crop, shifted how disciples supported their shaykh. Shaykhs within the Tijaniyya, Qadiriyya, and Bamba's new Muridiyya often sustained their learning communities through groundnut production, as colonial land grants enabled French groundnut production in Senegal's arid interiors. In this agricultural setting, addiya could take the form of a day set aside to work in a shaykh's fields or a share of a disciple's own harvest (Buggenhagen 2012: 84-85; Robinson 1991: 164-165; Stepan 2013: 211-212). Groundnut production was concentrated in the Peanut Basin, a region that encompasses Ndem, Mbakke Kajoor, and Touba, which would become the Muridiyya's holy city. This region has sandy soil suited for peanut production, yet the French focus on this cash crop forced agricultural methods that contributed to the region's long-term land degradation (Adams and So 1996: 34). Living within this economy, however, meant that peanut production was one's livelihood.

Labor not only sustained these growing communities economically; Bamba taught that it also was a spiritual act in itself. Ngom (2016: 75-77) states that Bamba's teachings on labor 
emphasized himma, or inner spiritual strength, which, if developed through intellectual and physical hard work, leads to spiritual illumination. Murid Ajamī sources, Ngom writes, contend that the early Muridiyya grew so quickly and developed such intense solidarity among its early disciples precisely because of their commitment to work as devotional practice. Labor became a significant part of the Muridiyya's origins, economy, discourse, and practice.

One of Bamba's most prominent disciples embodied the idea of labor as a devotional practice. Shaykh Ibrahima Fall (1858-1930) was a scholar and author of several books (Ngom 2009: 117-118; 2016: 96-99). He became Bamba's disciple in an act of allegiance in Mbakke Kajoor, which adds sacred significance to the site for the Baay Fall (Wolof: Father Fall) suborder of the Muridiyya. Baay Fall disciples recounted this event to me to explain why the site is important, emphasizing bätin, the mystical elements of djebel (submission) (interview, Soxna Aïssa Cissé, 7 June 2015; interview, Abdoulaye Ngom, 26 February 2016). Mbow (2017: 11) encapsulates the lineage of the Baay Fall tradition that started with Fall's first act of submission to Bamba: “The implementation of the Prophet Muhammad's (PBUH) mission, on Mbacké Kadior's land, ordained by Cheikh Ahmadou Bamba, necessitated an unprecedented step defying all reason, and Cheikh Ibrahima Fall held the key to that." Citing Fall's act of extraordinary submission and Bamba's lineage in Mbakke Kajoor in present-day discourse is a consciously repeated connection of the daara to its sacred history, emphasizing its role as a sacred place.

After he submitted to Bamba, Fall is known for his lifetime of absolute devotion to Bamba through labor. Ngom (2016: 97-99) notes that Fall and Bamba corresponded and collaborated in their emphasis on ethical living. Fall led Bamba's first school that combined ethical, spiritual, and vocational training. Baay Fall disciples believe that labor is a form of prayer, drawing from Bamba's teachings and Fall's example. They explain that they pray constantly through this labor. As Abdoulaye Ngom, a Baay Fall disciple in another town, told me, "Prayer is always on my lips," so he does not stop to pray five times a day (interview, 23 January 2016). Many within the majority-Muslim Senegalese society (including within other parts of the Muridiyya) criticize this practice, just as some of Bamba's other disciples criticized Fall's behavior during his lifetime. They said that Fall took labor as devotion to the extreme, neglecting spiritual study (Babou 2007: 64-65; Copans 1978: 242; Cruise O’Brien 1975: 50-51; Mbow 2000: 16-18; Ngom 2009: 117-118).

Present-day rural daaras continue to be focused on religious study and communal work, predominantly agricultural. For over a century, the Sahel region's environmental degradation, intensified by intermittent droughts and steadily rising temperatures, has made agricultural work across the Sahel more and more difficult. Work to rebuild sustainable agriculture in a hot and dry environment is a unifying goal in the Ndem and Mbakke Kajoor daaras, and was part of their design. Whether they are Baay Fall or non-Baay Fall, residents of the daaras look on labor as either religious practice or economic and environmental revitalization, or both.

\section{Labor as Religious Practice}

Sëriñ Babacar Mbow and his wife, Soxna Aïssa Cissé, started the Ndem daara in the 1980s to address the effects of severe drought in Senegal's central regions: food and water insecurity, loss of agricultural income, and unemployment. They designed the daara to integrate spiritual, economic, and environmental renewal. Cissé described the Ndem daara as a direct implementation of Bamba's teachings: "Each era has problems, and needs new ways to address those problems. In Sëriñ Touba's [Bamba's] plan, he said to pay a lot of attention to the environment, to create environments favorable for people" (interview, 26 June 2009). 
In 2014, Murid Khalife General Sëriñ Sidi Moukhtar Mbacké gave Mbow the directive (ndigal) to develop the Mbakke Kajoor daara. The ndigal is an important concept within the Muridiyya as an act of submission (Ngom 2009: 117-118). Even more important is following a shaykh's ndigal without question. When given the ndigal, it was not a decision about whether to submit to that directive, but in what form. It led to a discernment process to decide how to design the new daara at Mbakke Kajoor. Following Mbow's long-term focus on revitalizing the region's environment and economic prospects, as well as addressing spiritual needs, the new daara's design focused on spiritual study, opportunities for trade education, and organic agriculture. Similar to the Ndem daara, it applied Bamba's pedagogical goals: to create a place in which spiritual education is practice-oriented and open to people of all social classes and educational backgrounds. Murids across Senegal, especially but not exclusively Baay Falls, were attracted from its start to participate in the daara's work as a commitment to the entire Murid community: submission to the ndigal embodied through labor.

A number of people in both Ndem and Mbakke Kajoor have described their work in a difficult environment as impossible without spiritual strength, citing a commonly repeated Wolof proverb: mboolo mooy doole (unity creates strength). This proverb is often used in a secular context throughout Senegal, although daara residents use it to reinforce the idea that working as a community, in devotional practice, brings strength. While citing a secular proverb, they are also citing Bamba's teachings on himma (spiritual strength). It comes up conversationally in work contexts when daara residents discursively refer to their work as religious practice. Using the Wolof proverb as a motto, Farma Thiam posted it in large block letters on the wall of her sewing workshop in Ndem. Workers in the Mbakke Kajoor construction area, and those in both of the daaras' gardens, cited the proverb many times when telling me how they work together. In a example similar to the proverb, women working in Mbakke Kajoor's communal kitchen joked while working during one of my visits in 2016, singing the refrain "sa doole" (your strength) of Youssou Ndour's popular 2002 song “Sa Doole." In each of these instances, people added sacred meaning to their citation of a popular proverb or song. Labor with religious intention is both personally and collectively meaningful.

The work of both daaras attracts Muslims of varying Sufi affiliations and some non-Muslims. Work weekends in Mbakke Kajoor attract Murids (not all Baay Fall) who sometimes come from long distances to contribute their labor to construct, for example, the prayer hall or educational buildings. In my observations while participating in this work, and in images and videos from these work weekends that daara residents have sent to me, women and men worked on the construction site, carrying buckets of sand or laying cement block, while a number of women worked in the daara kitchen to prepare communal meals. Everyone does what they are able to do. As Mbow explained to a group of religious leaders in the city of Louga (8 June 2015), participatory labor was integrated into the plan for Mbakke Kajoor, allowing people to be a part of revitalizing an important site in their religious history. They are performing devotional practice on a sacred site, making the work meaningful in multiple ways. While building a place for prayer and education, they create their religious, submitted selves on a spiritual path.

In addition, Muslims and non-Muslims are attracted to the daaras' work because it focuses on revitalizing a degraded environment and an impoverished economy. Some of the daaras' visitors come from the surrounding region to learn organic farming techniques or specific trades. They return home and implement that knowledge, benefiting their families and communities. Some are European or West African international visitors, who want to learn about the work or to contribute specialized skills (such as irrigation methods or solar energy expertise). While not all are performing their work as devotional practice, their labor is creating their identities as people responsive to the needs of this region. They, too, cite Mbow's guidance on labor, but in a 
way that shows respect and commitment, not obeisance. Daara managers are adept at ensuring visitors' participation so that they can be a part of the community, learning visitors' skills and putting them to work on specific projects. No matter the visitors' intentions (prayer, spiritual education, addressing regional poverty, or learning sustainable environmental practices), living in the daara, whether on a short- or long-term basis, means participating in labor. Cissé pointed out one such European visitor one morning, exclaiming that he was not Baay Fall but embodied the Baay Fall spirit, working so hard and with such enthusiasm (conversation, 19 February 2016). Visitors become part of the community when contributing labor to any of the communal efforts at the daara.

\section{Religious Tolerance}

Daara residents in Ndem and Mbakke Kajoor connect ideas about tolerance to Murid teachings on ethical living. They also practice tolerance in ways supported by Senegal's state and shared by its diverse religious population. Senegal is often cited in studies of secular states that shape religious pluralisms. These studies argue that political secularisms are organizing forces for religious life, even creating its content (Asad 1992: 3-10; Bowen 2010: 681-682; Kane 2016: 160-161; Kuru and Stepan 2012: 95; Mahmood 2016: 1-4; Soares and Osella 2009: S9-S13).

A newly independent state in 1960, Senegal relied on religious leadership to help rebuild infrastructure and social services after colonial rule. The first constitution created a secular state separate from religious affiliation, and explicitly provided freedom for religious institutions and public religious dialogue. Subsequent constitutions, including the most recent 2001 Constitution, have upheld these freedoms. These provisions are applicable to all religious affiliations, both Muslim and non-Muslim. While separate from the state and not uniform in their perspectives or actions, religious authorities advise the state on social matters and take leadership on projects of social benefit, such as rural economic programs or educational initiatives (Camara and Seck 2010: 871873; Stepan 2013: 215-217). These reciprocal relationships create and sustain the ideal of religious tolerance as part of the nation's culture and identity. The state, religious leadership, and the Senegalese public consciously work to uphold it, even when they disagree (Babou 2013: 137-141; Stepan 2013: 215-218; Villalón 1999: 129). Conflicts between religious groups exist, although many contemporary Senegalese religious leaders make a point of having positive relationships with other religious communities, as do their adherents. They join each other's religious holiday feasts, help each other with building projects, and make public declarations about religious tolerance (Cochrane 2016: 7; Riley 2019: 121-122; Stepan 2013: 218-220). Their unity comes from shared but not monolithic values: each group cites tolerance in their specific traditions.

Discussions of tolerance permeate Mbow's writings on Baay Fall, Murid, and Sufi theology. Mbow (2001: 4-5) describes the unity and universality present in Bamba's teachings as embodied in practices of the contemporary Muridiyya: "The impersonal and universal character of his [Bamba's] teachings is notably confirmed by the extraordinary proliferation of Murid dahiras [Murid community and study centers] in Africa as well as in other continents. Characterized by a foundational ethic centered on solidarity, unity, and tolerance, these dahiras constitute the important centers of the vernacularization of the Shaykh's Path, blessed and approved by the All-Forgiving (Al-Ghafûr)." As extensions of Bamba's teachings in the modern world, dahiras are places of spiritual study, where people can intentionally practice "solidarity, unity, and tolerance" with others. Mbow reiterates this in his conversations with and even treatment of his disciples, no matter their abilities or roles in the daara. His messaging echoes Bamba's teachings that equal treatment and intentional inclusion of all, no matter their ethnic or class background, is part of 
moral and ethical behavior (Ngom 2016: 58-59). In an interview, Mbow linked practices of labor and tolerance in this explanation of the daara: "The objective is the spirit of sharing, you see. The projects [include] men and women, Christians and Muslims, those who practice the occult, without discrimination" (interview, 1 June 2018). In both statements, he echoed Bamba's teachings on ethical living: the importance of practicing tolerance in everyday life. Mbow referred to these teachings as both specifically Murid and universally applied. He has made the daaras open to all, seeing communal practices of Bamba's teachings as universal connecting points.

Tolerance, however, is not passive permissiveness but active respect. Scholars of Senegalese politics have linked what Stepan (2013: 215-221) calls consciously performed 'rituals of respect' to the cultivation of tolerance in political, ceremonial, and everyday life (see also Dieng 2015: 87). Everyday examples that are prevalent in the daaras are discussed in terms of religious teachings. Mbow requires all visitors and residents to adhere to certain guidelines about comportment: modest dress (defined by rural Senegalese cultural norms), no smoking or drinking, and treating others with respect. If someone needs to correct a co-worker, they do it in a way that respects that colleague's expertise. Disagreements are handled with a calm demeanor, often involving a mutually trusted elder or work manager as mediator. The people who have been asked to leave were anomalies: they were disruptive in some way, or did not listen to repeated requests to change their behavior.

These behavioral guidelines can be followed no matter one's religious affiliation: they define what it means to show respect for the community and create a community-wide culture of tolerance toward all. For example, Jacoba Sy worked as a guard for Ndem's artisanal campus for a number of years. In this role, he knew all the workers, and was able to sense times when they needed an encouraging word. He used his role as a voice of calm during conflicts, contributing to a culture of tolerance in the workplace, sometimes reciting a Qur'anic verse or a line from Bamba's poetry to clarify how he was consciously reproducing these teachings in his actions. Others in both daaras are known for having a welcoming home courtyard for convivial evening visiting, for being a trusted counselor, or for being a person who can assist with a carpentry or repair job. Each person extends respect to others, deliberately employing these acts as religious practice of both labor and tolerance.

Respect extends to Mbow. The daara residents who are Mbow's disciples submit to his spiritual guidance; those who are not his disciples defer to his direction. Either way, people pay close attention to Mbow's words and actions and show respect for him. Bodily practices that show this respect include following his direction, kneeling or bowing in his presence, opening one's hands for his blessing, and respectful silence while he is talking. These specific practices, expected when in the presence of a shaykh, are not unique to these daaras or to the Muridiyya. Disciples perform a greater depth of these actions as acts of complete submission, although non-disciples also perform this embodied respect. Along with this respectful relationship with Mbow, choosing to live in a daara for those of any religious affiliation is choosing to follow a shaykh's guidelines and participate in the daara's activities. Respect for Mbow is an inherent part of the culture of both daaras, allowing Mbow to implement-and the community to better adhere to-his guidance on tolerance.

Along with comportment, tolerance on an interpersonal level takes the form of everyday discourse. Jacoba Sy expressed the idea of individual commitment to tolerance as a religious principle: "Sëriñ Babacar says that one must have tolerance, patience, and abstinence. Tolerance is very important. Baay Falls must be tolerant. Tolerance is purely spiritual. It doesn't matter what you tolerate: you must tolerate everything" (interview, 15 June 2015; quoted in Cochrane 2017: 50). For Sy, tolerance is an everyday practice, not always an easy one, and a religious act. Citing Mbow's words adds authority to Sy's discussion. 
Respecting each person's individual path is a common metaphor when talking about tolerance. Path (tariqa) is a synonym for a Sufi order and refers to each order's path toward illumination. It is not separate from but guides one's entire life. Metaphors about lights (the shaykhs) along a darkened path also describe the need for everyday spiritual guidance. Moussa Diène is a long-time Baay Fall resident of Ndem who was raised Tijani. His son chose a Murid instead of a Baay Fall spiritual guide. Diène told me he respected his son's choice because it is spiritually informed. Diène said: "You can't force someone. Each person here has the responsibility to choose a path" (interview, 4 June 2015). Moussa Diack, another Ndem resident, described his own journey from being raised Tijani and converting to Baay Fall: "Each person has his own way of finding peace. Each person has his path" (interview, 5 June 2013).

Tolerance is a practiced and discussed part of religious and social life, a national identity, and a political policy. Performing tolerance through everyday actions and community-wide guidelines contributes to the daaras' sense of community.

\section{Conclusion: A Culture of Labor and Tolerance}

Studying what unifies people has a long history within the social sciences. Durkheim's (1915: 224-229) idea that society becomes more than a collection of individuals, and that it unifies individuals, came from psychological insights as well as studies of social, political, and religious life (see also Falasca-Zamponi 2014: 45-48). Early-twentieth-century anthropologists wrote about the everyday practices that create solidarity. Recent ethnographic work, highlighted above, has explored the cultivation of the religious self as well as its political and social contexts. Since its origins, though, Islamic scholarship, and specifically the West African Islamic intellectual tradition, has dealt with both the political and the individual, and with unity as well as conflict (Kane 2016: 10-11; Launay 2016: 13-14; Ware 2014: 1-4; Wright 2020: 4-6).

Mbow and other contemporary shaykhs cite this intellectual tradition in their contemporary teachings and work. In the daaras, Mbow and residents described everyday purposeful practices as part of their spiritual path, which was informed by tradition that was broadly significant, both politically and socially. From their perspective, each daara's sense of community comes from laboring together to restore spiritual, economic, and environmental well-being in an environmentally degraded region. It is communal life that emulates the tradition that Bamba, Sufi scholars before him, and Murid scholars after him developed. Bamba cited intellectual traditions to create a pedagogy and learning communities that could address the environmental and political situations of his era. His intellectual and spiritual descendants likewise use his model to address present-day challenges. Whether one is a disciple or not, the daara's unity comes from specific practices and discourses that directly cite religious traditions.

While the daaras' religious affiliation and majority are Baay Fall, their religious practices resonate with more than just Baay Fall adherents. Living in a daara, practicing tolerance toward others, and contributing labor is performative individually. Each person creates their self as a devoted Muslim, a Murid, a Baay Fall, a disciple of Mbow, a religious seeker, someone dedicated to addressing chronic poverty and environmental degradation, or a combination of the above. The daaras cite the Murid tradition not only to create community and a place for Qur'anic education, but also to do the difficult work of environmental revitalization. Individually and communally practicing shared values, in a place built on those shared values, with embodied and discursive practices of those values consciously embedded in everyday life, creates intentionally unified communities. 


\section{ACKNOWLEDGMENTS}

The author thanks the residents of the Ndem and Mbakke Kajoor daaras, particularly Sërin Babacar Mbow and Soxna Aïssa Cissé, for their welcome and insights. She also thanks Chantal Tetrault and Sarah Hillewaert for organizing this special section.

LAURA L. COCHRANE is a Professor of Anthropology at Central Michigan University. Her longitudinal research in Senegal concerns religious discourse, gardening, and artisanal production, all in the context of the Sahel region's economic and environmental challenges. She is the author of Weaving through Islam in Senegal (2012), Everyday Faith in Sufi Senegal (2017), Adventure as Education: John W. Bennett and Anthropology in the Early Twentieth Century (2019), and has published articles in anthropology and African studies journals. E-mail: cochr1ll@cmich.edu

\section{REFERENCES}

Abenante, Paola, and Daniele Cantini. 2014. "Introduction: Life-Worlds and Religious Commitment: Ethnographic Perspectives on Subjectivity and Islam." La Ricerca Folklorica 69: 3-19.

Abu-Lughod, Lila. 2006. “The Debate about Gender, Religion, and Rights: Thoughts of a Middle East Anthropologist." PMLA 121 (5): 1621-1630.

Adams, Adrian, and Jaabe So. 1996. A Claim to Land by the River: A Household in Senegal 1720-1994. Oxford: Oxford University Press.

Asad, Talal. 1992. "Religion and Politics: An Introduction." Social Research 59 (1): 3-16.

Asad, Talal. 2015. "Thinking about Tradition, Religion, and Politics in Egypt Today." Critical Inquiry 42 (1): $166-214$.

Augis, Erin. 2014. “Aïcha’s Sounith Hair Salon: Friendship, Profit, and Resistance in Dakar." Islamic Africa 5 (2): 199-224. http://www.jstor.org/stable/islamicafrica.5.2.199.

Babou, Cheikh Anta. 2003. "Educating the Murid: Theory and Practices of Education in Amadu Bamba's Thought." Journal of Religion in Africa 33 (3): 310-327.

Babou, Cheikh Anta. 2007. Fighting the Greater Jihad: Amadu Bamba and the Founding of the Muridiyya of Senegal, 1853-1913. Athens: Ohio University Press.

Babou, Cheikh Anta Mbacké. 2009. "Généalogie, éducation, et baraka (grâce divine) dans la famille Mbakke: Une exploration de quelques sources de l'autorité spirituelle d’Amadu Bamba” [Genealogy, education, and baraka (divine grace) in the Mbakke family: An exploration of the spiritual authority of Amadu Bamba]. Afrique \& Histoire 7 (1): 199-234.

Babou, Cheikh Anta. 2013. “The Senegalese 'Social Contract' Revisited: The Muridiyya Muslim Order and State Politics in Postcolonial Senegal." In Diouf 2013, 125-146.

Batran, Abdal-Aziz. 1973. "An Introductory Note on the Impact of Sidi al-Mukhtar al-Kunti (17281811) on West African Islam in the 18th and 19th Centuries." Journal of the Historical Society of Nigeria 6 (4): 347-352.

Bondaz, Julien, and Julien Bonhomme. 2014. “Don, sacrifice et sorcellerie: Léconomie morale de l'aumône au Sénégal” [Gift, sacrifice, and sorcery: The moral economy of almsgiving in Senegal]. Annales: Histoire, Sciences Sociales 69 (2): 471-504. https://muse.jhu.edu/article/555283.

Bowen, John R. 2010. "Secularism: Political Genealogy or Political Dilemma?" Comparative Studies in Society and History 52 (3): 680-694. https://doi.org/10.1017/S0010417510000356.

Buggenhagen, Beth. 2011. “Are Births Just 'Women's Business'? Gift Exchange, Value, and Global Volatility in Muslim Senegal.” American Ethnologist 38 (4): 714-732. https://doi. org/10.1111/j.1548-1425.2011.01332.x. 
Buggenhagen, Beth. 2012. Muslim Families in Global Senegal: Money Takes Care of Shame. Bloomington: Indiana University Press.

Camara, Fatou Kiné, and Abdourahmane Seck. 2010. "Secularity and Freedom of Religion in Senegal: Between a Constitutional Rock and a Hard Reality." BYU Law Review 10 (3): 859-884.

Cochrane, Laura L. 2016. "Bamba Merci: The Intersections of Political and Spiritual Graffiti in Senegal." African Identities 14 (1): 3-18. https://doi.org/10.1080/14725843.2015.1100106.

Cochrane, Laura L. 2017. Everyday Faith in Sufi Senegal. London: Routledge Press.

Cochrane, Laura L. 2021. "Religious Networks and Small Businesses in Senegal." Economic Anthropology 8 (1): 22-33.

Copans, Jean. 1978. "Paysannerie et politique du Sénégal” [Peasantry and politics of Senegal]. Cahiers d'Études Africaines 18 (69-70): 241-256.

Covington-Ward, Yolanda. 2016. Gesture and Power: Religion, Nationalism, and Everyday Performance in Congo. Durham, NC: Duke University Press.

Cruise O'Brien, Donal B. 1975. Saints and Politicians: Essays in the Organisation of a Senegalese Peasant Society. Cambridge: Cambridge University Press.

Dieng, Moda. 2015. "La contribution des jeunes à l’alternance politique au Sénégal: Le rôle de Bul faale et de Y'en a marre" [The contribution of young people to political alternation in Senegal: The role of Bul Faale and Y'en a Marre]. African Sociological Review 19 (2): 75-95.

Diouf, Mamadou, ed. 2013. Tolerance, Democracy, and Sufis in Senegal. New York: Columbia University Press.

Durkheim, Émile. 1915. The Elementary Forms of the Religious Life. Trans. Joseph Ward Swain. London: George Allen \& Unwin.

Falasca-Zamponi, Simonetta. 2014. "Society as Representation: Durkheim, Psychology and the 'Dualism of Human Nature.” Durkheimian Studies (n.s.) 20: 43-63. https://www.jstor.org/stable/44174118.

Fioratta, Susanna. 2020. Global Nomads: An Ethnography of Migration, Islam, and Politics in West Africa. New York: Oxford University Press.

Goodman, Jane E. 2002. "Writing Empire, Underwriting Nation: Discursive Histories of Kabyle Berber Oral Texts." American Ethnologist 29 (1): 86-122. https://www.jstor.org/stable/3095022.

Goodman, Jane E., Matt Tomlinson, and Justin B. Richland. 2014. "Citational Practices: Knowledge, Personhood, and Subjectivity." Annual Review of Anthropology 43: 449-463. https://www.annualreviews. org/doi/10.1146/annurev-anthro-102313-025828.

Heck, Paul L. 2006. "Mysticism as Morality: The Case of Sufism.” Journal of Religious Ethics 34 (2): 253-286.

Hill, Joseph. 2018. Wrapping Authority: Women Islamic Leaders in a Sufi Movement in Dakar, Senegal. Toronto: University of Toronto Press.

Janson, Marloes. 2016. “'How, for God's Sake, Can I Be a Good Muslim?': Gambian Youth in Search of a Moral Lifestyle." Ethnography 17 (1): 22-46. https://doi.org/10.1177/1466138115575655.

Kane, Ousmane. 2016. Beyond Timbuktu: An Intellectual History of Muslim West Africa. Cambridge, MA: Harvard University Press.

Kuru, Ahmet T., and Alfred Stepan. 2012. "Laïcité as an 'Ideal Type' and a Continuum: Comparing Turkey, France, and Senegal." In Democracy, Islam, and Secularism in Turkey, ed. Ahmet T. Kuru and Alfred Stepan, 95-121. New York: Columbia University Press.

Launay, Robert. 2016. "Introduction: Writing Boards and Blackboards." In Islamic Education in Africa: Writing Boards and Blackboards, ed. Robert Launay, 1-26. Bloomington: Indiana University Press.

Leichtman, Mara A. 2015. Shi' $i$ Cosmopolitanisms in Africa: Lebanese Migration and Religious Conversion in Senegal. Bloomington: Indiana University Press.

Mahmood, Saba. 2016. Religious Difference in a Secular Age: A Minority Report. Princeton, NJ: Princeton University Press.

Masquelier, Adeline. 2015. "Qur'an Schooling and the Production of Mindful Bodies in West Africa." Journal of Africana Religions 3 (2): 184-192.

Mbow, Serigne Babacar. 2000. La voie Baye Fall, ou la lumière du dedans [The Baye Fall path, or the light within]. Dakar: ECARICOM. 
Mbow, Serigne Babacar. 2001. La lumière de léternel, ou Khadimou Rassôl [The eternal light, or Khadimou Rassôl]. Dakar: ECARICOM.

Mbow, Serigne Babacar. 2017. Cheikh Ahmadou Bamba: La suprême recours [Cheikh Ahmadou Bamba: The supreme recourse]. Bambey: Éditions Maam Samba.

Mittermaier, Amira. 2019. Giving to God: Islamic Charity in Revolutionary Times. Oakland: University of California Press.

Nakassis, Constantine V. 2012. "Brand, Citationality, Performativity." American Anthropologist 114 (4): 624-638. https://doi.org/10.1111/j.1548-1433.2012.01511.x.

Ndiaye, Saliou. 2015. "Unité essentielle des voies Soufis dans la pratique spirituelle de Cheikh Ahmadou Bamba" [Essential unity in the Sufi ways in the spiritual practice of Cheikh Ahmadou Bamba]. Annales de la Faculté des Lettres et Sciences Humaines 44-45/A: 113-126.

Ngom, Fallou. 2009. "Ahmadu Bamba's Pedagogy and the Development of 'Ajamī Literature." African Studies Review 52 (1): 99-123.

Ngom, Fallou. 2015. "Murid Ajami Sources of Knowledge: The Myth and the Reality." In From Dust to Digital: Ten Years of the Endangered Archives Programme, ed. Maja Kominko, 331-376. Cambridge: Open Book Publishers.

Ngom, Fallou. 2016. Muslims beyond the Arab World: The Odyssey of 'Ajamī and the Murìdiyya. New York: Oxford University Press.

Riley, Emily. 2019. “Guests of God': The Layene, and Urban Sufi Community of Dakar, Senegal." Africa Today 66 (1): 117-140. https://muse.jhu.edu/article/741341.

Robinson, David. 1991. "Beyond Resistance and Collaboration: Amadu Bamba and the Murids of Senegal." Journal of Religion in Africa 21 (2): 149-171. https://www.jstor.org/stable/1580803.

Soares, Benjamin, and Filippo Osella. 2009. "Islam, Politics, Anthropology." Journal of the Royal Anthropological Institute 15: S1-S23.

Stepan, Alfred. 2013. "Stateness, Democracy, and Respect: Senegal in Comparative Perspective." In Diouf 2013, 205-238.

Thompson, Katrina Daly. 2019. “Becoming Muslims with a 'Queer Voice': Indexical Disjuncture in the Talk of LGBT Members of the Progressive Muslim Community." Journal of Linguistic Anthropology 30 (1): 123-144. https://doi.org/10.1111/jola.12256.

Villalón, Leonardo A. 1999. "Generational Changes, Political Stagnation, and the Evolving Dynamics of Religion and Politics in Senegal." Africa Today 46 (3-4): 129-147.

Ware, Rudolph T., III. 2014. The Walking Quran: Islamic Education, Embodied Knowledge, and History in West Africa. Chapel Hill: University of North Carolina Press.

Wright, Zachary Valentine. 2020. Realizing Islam: The Tijaniyya in North Africa and the Eighteenth-Century Muslim World. Chapel Hill: University of North Carolina Press. 